\title{
Against Hybrid Expressivist-Error Theory
}

\author{
Wouter F. Kalf ${ }^{1}$
}

Published online: 3 June 2016

(C) The Author(s) 2016. This article is published with open access at Springerlink.com

\section{Introduction}

Consider moral judgments like 'stealing is morally wrong' and 'helping the poor is morally right.' Cognitivists think that moral judgments express truth-apt beliefs. Cognitivist success theorists think that some moral judgments are true because the truth-makers they require exist. ${ }^{1}$ Cognitivist error theorists think that no moral judgment is true because the truth-makers they require do not exist. ${ }^{2}$ Non-cognitivists think that moral judgments express non-truth-apt non-cognitive states like desires or emotions. ${ }^{3}$ Quasi-realists are non-cognitivists who attempt to earn the right to speak about ethics as cognitivist success theorists do, which includes speaking about moral truth and moral objectivity, but without abandoning the claim that moral judgments express, at least in the first instance, non-truth-apt non-cognitive states. ${ }^{4}$

\footnotetext{
1 See for instance David Enoch, Taking Morality Seriously (Oxford: Oxford University Press, 2011).

2 See John L. Mackie, Ethics (Harmondsworth: Penguin Books, 1977); also see Richard Joyce, The Myth of Morality (Cambridge: Cambridge University Press, 2001); Charles Pigden, "Nihilism, Nietzsche and the Doppelganger Problem," Ethical Theory and Moral Practice, vol. 10, no. 5 (2007): 414-456; Bart Streumer, "Can We Believe the Error Theory?" Journal of Philosophy, vol. 110, no. 4 (2013): 194-212; Jonas Olson, Moral Error Theory (Oxford: Oxford University Press, 2014). For the plausibility of error theory it matters a great deal whether moral judgments are said to be systematically false, untrue, or unjustified. I return to this issue in $\$ 4$ and will in the meantime write, for simplicity, that error theory states that all moral judgments are false.

3 See Alfred J. Ayer, Language, Truth and Logic (New York: Dover, 1936).

4 See Simon Blackburn, Essays in Quasi-Realism (Oxford: Oxford University Press, 1993; also see Allan Gibbard, Thinking How to Live (Cambridge, MA: Harvard University Press, 2003).
}

Wouter F. Kalf

kalfwf@gmail.com; w.f.kalf@uu.nl

1 Utrecht University, Utrecht, The Netherlands 
Recent metaethical debate has seen a growing interest in hybrid theories of moral judgment. Hybrid theories state that moral judgments express both cognitive and non-cognitive states. ${ }^{5}$ An example of such a theory is Toby Svoboda's hybrid expressivist-error theory. ${ }^{6}$ Expressivists, as Svoboda uses the term, are noncognitivists who do not have the quasi-realist agenda. They accept "that moral utterances are neither true nor false, because they are used to express attitudes".7 Hybrid expressivist-error theory combines elements of expressivism (thus understood) and error theory into a single theory of moral judgment.

Svoboda has three arguments for hybrid expressivist-error theory and against pure error theory. I argue that these arguments don't work (Svoboda also has arguments against the pure expressivist but I will not consider these in this paper). I start by giving a more detailed explanation of hybrid expressivist-error theory and I explain its appeal (\$2). I then discuss Svoboda's first argument, which is that error theory cannot account for contributions to moral discourse, like imperatives such as 'Don't steal!' that seem to call for a non-cognitivist analysis, that hybrid expressivist-error theory can account for such contributions, and that we should therefore accept the hybrid view. I call this the imperative argument. I think that the imperative argument gets to the heart of an important issue for error theory that is too often brushed aside on the grounds that it has an easy solution. ${ }^{8}$ The issue is about what error theory, which tends to focus on non-negative atomic moral judgments like 'stealing is morally wrong,' should say about non-atomic moral judgments, including modal judgments like 'stealing might be morally wrong' and imperatives. The easy solution, accepted by most error theorists, is to limit the set of moral judgments to which error theory applies to non-negative atomic moral judgments. ${ }^{9}$ I argue that there are three problems with the easy solution. I continue to argue that Svoboda's original formulation of the imperative argument fails because it fails to show that the easy solution does not work (§3). After this I improve Svoboda's imperative argument so that it no longer fails for this reason

\footnotetext{
5 See, among others, Daniel R. Boisvert, "Expressive-Assertivism," Pacific Philosophical Quarterly, vol. 89, no. 2 (2008): 169-203; also see David Copp, "Realist Expressivism: A Neglected Option for Moral Realism," Social Philosophy and Policy, vol. 18, no. 2 (2001): 1-43; Ryan Hay, "Hybrid Expressivism and the Analogy between Pejoratives and Moral Language" European Journal of Philosophy, vol. 21, no. 3 (2013): 450-474; Michael Ridge, "Ecumenical Expressivism: Finessing Frege"" Ethics, vol. 116, no. 2 (2006): 302-336; Mark Schroeder, "Hybrid Expressivism: Virtues and Vices," Ethics, vol. 119, no. 2 (2009): 257-309.

6 See Toby Svoboda, "Hybridizing Moral Expressivism and Moral Error Theory," Journal of Value Inquiry, vol. 45, no. 1 (2011): 37-38; also see Guy Fletcher, "Moral Utterances, Attitude Expression, and Implicature" in G. Fletcher and M. Ridge (eds.) Having it Both Ways: Hybrid Theories and Modern Metaethics (Oxford: Oxford University Press, 2014), p. 173n1.

7 See Svoboda, op. cit., p. 37.

8 Also see Wouter F. Kalf, "Moral Error Theory, Entailment and Presupposition," Ethical Theory and Moral Practice, vol. 16, no. 5 (2013): 923-937.

9 See Richard Joyce, "Moral Anti-Realism," in E.N. Zalta (ed.), Stanford Encyclopedia of Philosophy, §4; also see Pigden 2007, op. cit., p. 451; Walter Sinnott-Armstrong, Moral Skepticisms, New York: Oxford University Press, 2006), pp. 34-6.
} 
(§4). But then I argue that this improved imperative argument is either implausible (if we assume that moral judgments express either beliefs or desires) or overstated (if we assume that moral judgments express both beliefs and desires) (§5-6). I also argue that Svoboda's second and third arguments for the hybrid view and against pure error theory, which concern moral motivation and radical error, fail as well (§7). I have much less to say about moral motivation and radical error because these are well-trodden topics in the literature, and my complaint is that Svoboda hasn't done enough to convince the error theorist that her position is weaker than Svoboda's hybrid theory. A conclusion summarises my arguments (§8).

\section{Hybrid Expressivist-Error Theory}

In the previous section I spoke loosely about moral judgment, but here I will be more precise. Following Guy Fletcher and Michael Ridge I will say that a metaethical theory counts as a hybrid theory

just in case it satisfies one of the following two criteria: (i) [moral] claims express both belief-like and desire-like mental states [or] (ii) [moral] judgments are constituted by both belief-like and desire-like components. ${ }^{10}$

Take the total set of moral convictions, which is I term I appropriate to refer to both claims on the level of moral language (moral claims) and judgments on the level of moral thought (moral judgments). We have a hybrid theory just in case moral claims express both belief-like and desire-like mental states or if moral judgments are constituted by belief-like and desire-like components, where this 'or' is an inclusive or.

The plausibility of hybrid views in metaethics derives mainly from their ability to provide better explanations of a number of important features of moral convictions and moral discourse than either pure cognitivism on its own or pure non-cognitivism on its own. First, take the datum that there is a link between (making a) moral judgment and motivation to act. Suppose moral judgments are constituted by just desire-like components and that a broadly Humean moral psychology is correct, according to which desires motivate and beliefs do not motivate. In that case, noncognitivism's explanation of moral motivation is obvious and cognitivism, because it says that moral judgments are composed of motivationally inert states, is less plausible. This remains true even if cognitivism manages to explain moral motivation, since the cognitivist explanation will be (much) more complicated.

Second, take the datum that cognitivist theories have no Frege-Geach problem when it comes to explaining the logical validity of arguments that contain embedded moral claims. ${ }^{11}$ The problem for non-cognitivists is that moral claims cannot be said to express desire-like states when they are embedded in non-assertoric contexts. But once we fix this by giving moral claims a different meaning in these contexts then

\footnotetext{
${ }^{10}$ Guy Fletcher and Michael Ridge, "Introduction" in G. Fletcher and M. Ridge (eds.) Having it Both Ways: Hybrid Theories and Modern Metaethics (Oxford: Oxford University Press, 2014), p. ix (italics in original).

11 This objection traces to Peter Geach, “Ascriptivism," Philosophical Review, vol. 69, no. 2 (1960): 221-225. (Geach invokes Frege, hence the name Frege-Geach problem).
} 
arguments that seem valid, for instance because they apply modus ponens, equivocate.

Both cognitivists and non-cognitivists have attempted to find solutions to these problems. Cognitivists emphasize that the relation between making a moral judgment and being motivated does not obtain as ubiquitously and is not as strong as pure non-cognitivists claim. This means that pure cognitivists can explain what remains to be explained with their preferred externalist theory of motivation and do not require an internalist, necessary connection between moral judgment and motivation. ${ }^{12}$ And non-cognitivists claim that arguments that feature embedded moral claims have a kind of validity that need not have the same theoretically demanding "inference-licensing property" as arguments that do not feature moral claims. ${ }^{13}$ This means that pure non-cognitivists can explain what remains to be explained with their preferred "logic of attitudes." 14

These solutions are not widely accepted, however, and at this point in the dialectic a natural thought is that a hybrid theory, because it combines elements of pure cognitivism and pure non-cognitivism, is more plausible than either just pure cognitivism on its own or just pure non-cognitivism on its own. The central, driving idea is that since on hybrid views, moral claims express both belief-like and desirelike mental states, or that as moral judgments are constituted by both belief-like and desire-like components, these problems (and others besides) can be solved. Simply appeal to the desire-like features of moral judgments when you need to explain moral motivation and simply appeal to the belief-like features of moral claims when you need to solve the Frege-Geach problem. As John Eriksson puts it, "the best theory must strike a balance between expressivism and cognitivism-thus capturing the merits of both." 15

The hybrid expressivist-error theorist can accept all of this. The fact that she adds that the beliefs that moral convictions express are all false does not mean that she cannot solve the Frege-Geach problem, for that problem is just about semantics and not (also) about metaphysics. Moreover, the falsity of all moral beliefs also clearly doesn't mean that she cannot use the desire-like features of moral convictions to explain their motivational power.

So far, and following Fletcher and Ridge, we have discussed hybrid theories which accept that moral claims express beliefs and desires or that moral judgments are constituted by belief-like and desire-like components. One difficulty for this classification is that hybrid theories can take either cognitivism or non-cognitivism as their main component and that "it is not entirely trivial to explain how this distinction is best drawn." ${ }^{16}$ When is a theory of moral convictions a predominantly

\footnotetext{
12 See David O. Brink, Moral Realism and the Foundations of Ethics (Cambridge: Cambridge University Press, 1989), pp. 37-80.

13 See Schroeder, op. cit., p. 266.

14 See Simon Blackburn, “Attitudes and Contents," Ethics, vol. 98, no. 3 (1988): 501-517.

15 See John Eriksson, "Hybrid Expressivism" in G. Fletcher and M. Ridge (eds.) Having it Both Ways: Hybrid Theories and Modern Metaethics (Oxford: Oxford University Press, 2014), p. 149.

16 See Fletcher and Ridge, op. cit., p. x.
} 
cognitivist theory with non-cognitivist embellishments, and when is it a mainly noncognitivist theory with cognitivist additions?

There is a second difficulty as well. Svoboda thinks that a view on which some moral claims fully demand an expressivist semantics and on which all other moral claims fully demand a cognitivist semantics - and so on which no moral claim expresses both a belief and a desire-is also a version of hybridism:

a hybrid expressivist-error theorist treats every moral [claim] as either an expression of a speaker's attitude or an expression of a false belief. For the sake of simplicity, let us assume that any moral [claim] is used to express either an attitude or a belief ${ }^{17}$

Is it plausible to call this kind of view a hybrid view? Perhaps not, given that the term 'hybrid' is normally used in the literature to refer to theories according to which moral judgments or claims express both beliefs and desires (and perhaps Svoboda should have invented a different term in order to avoid misunderstandings). But forget about labelling and consider the idea. Take all moral claims; some of them must get a purely cognitivist semantics and all the others must get a purely expressivist semantics. This looks like a possible position in the logical space of metaethical options. I will argue in $\$ 3$ that error theorists ought to take this kind of view seriously. Note that this 'ought' is an epistemic ought. I assume in this paper that the companions in guilt objection to moral error theory, according to which, at least on one formulation, the non-existence of moral normativity would entail, implausibly, the non-existence of epistemic normativity, fails. ${ }^{18}$

So assuming for the moment that we now have an extra possibility for a hybrid theory, the following versions of hybrid expressivist-error theory are all possible (and exhaust our options):

(1) Some moral claims must be understood just along non-cognitivist semantic lines and every other moral claim must be understood just along cognitivist semantic lines

(2) Every moral claim must be understood as combining elements of noncognitivist and cognitivist semantics and never just along non-cognitivist semantic lines and never just along cognitivist semantic lines

(3) Some moral claims must be understood just along non-cognitivist semantic lines, some other moral claims must be understood just along cognitivist semantic lines and the remaining moral claims must be understood as combining elements of non-cognitivist and cognitivist semantics

\footnotetext{
17 Op. cit., p. 38. In a somewhat similar vein, Ridge writes: "There is logical space for a hybrid view according to which some but not all moral utterances express beliefs which provide their truth-conditions ... classifying them as hybrid views is plausible (op. cit., p. 307)." This is 'somewhat similar' to what Svoboda says because Ridge, though he agrees that views on which not all moral claims express both beliefs and desires can still qualify as a hybrid view, does not say that we can have a hybrid view if all claims either express just beliefs or else express just desires.

18 See Terence Cuneo, The Normative Web (Oxford: Oxford University Press, 2007); also see Richard Rowland, "Moral Error Theory and the Argument from Epistemic Reasons," Journal of Ethics and Social Philosophy, vol. 7, no. 1 (2013): 1-24, p. 1.
} 
(4) Some moral claims must be understood along cognitivist lines and every other moral claim must be understood as combining cognitivist and noncognitivist semantics

(5) Some moral claims must be understood along non-cognitivist lines and every other moral claim must be understood as combining cognitivist and noncognitivist semantics

These versions of hybrid expressivist-error theory just consider claims on the level of moral semantics (moral claims). They do not mention judgments on the level of moral thought (moral judgments). This is because I will now discuss the imperative objection to error theory that wholly operates on the level of semantics and ask: given this objection, are any of these theses (1)-(5) more plausible than pure error theory? I argue that none of them is and turn, in the penultimate section, to moral motivation and radical error as alleged reasons to prefer hybrid expressivist-error theory to pure error theory.

\section{The Simple Imperative Argument}

Svoboda's first argument in favour of hybrid expressivist-error theory and against pure error theory goes as follows:

The first advantage of a hybrid expressivist-error theory over pure error theory is that pure error theorists treat all moral [claims] as expressions of false beliefs and thus have difficulty accounting for moral [claims] that seem to be used to express attitudes rather than beliefs. [Take 'Stop war!'] This moral [claim] seems to be used to express disapproval of war rather than any belief about war, because [it] has the grammatical form of an imperative rather than an assertion ... Since expressions of attitudes are neither true nor false, this is a counter-example to the pure error theorist's thesis that all moral [claims] are used to express false beliefs. To retain their thesis, pure error theorists must claim implausibly that appearances are misleading in this case and that ['Stop war!'] really is used to express a belief, for example that war is wrong ... All else being equal this provides grounds to accept a hybrid theory over pure error theory ${ }^{19}$

I call this the Simple Imperative Argument. We can formalise it as follows:

\section{Simple Imperative Argument}

\footnotetext{
19 See Svoboda, op. cit., pp. 43-4 (my italics). Svoboda's uses 'Down with war!' but I prefer 'Stop war!' as the latter is much more clearly imperatival. After all, 'Close the door!' - an uncontroversial example of an imperative - and 'Stop war!' both provide a clear instruction as to what to do. This does not hold for 'Down with war!' This 'imperative,' if it is one, can be followed by withdrawing 15 soldiers, stopping one war, cutting defense expenses by roughly a third, et cetera. In an attempt to put these needlessly distracting considerations aside, I will use 'Stop war!' See Daniel Boisvert, "Expressivism, Nondeclaratives, and Success-Conditional Semantics," in G. Fletcher and M. Ridge (eds.) Having it Both Ways: Hybrid Theories and Modern Metaethics (Oxford: Oxford University Press, 2014), p. 25.
} 
P1 The semantics of all moral claims must be explained ${ }^{20}$

P2 The only explanation that error theorists, being cognitivists, can give is that all moral claims express (false) beliefs

P3 Imperatives provide a counter-example to pure error theory because they express non-truth-apt desires

P4 Hybrid expressivist-error theory does not face this counter-example, as it can say that imperatives express non-truth-apt desires

C1 Therefore, error theory should be turned into hybrid expressivist-error theory [From P1-P4].

If we recall Svoboda's assumption that all moral claims either just express beliefs or else just express desires then the Simple Imperative Argument vindicates version (1) of hybrid expressivist-error theory: some moral claims (viz., imperatives) must be understood just along non-cognitivist semantic lines and every other moral claim (e.g., non-negative atomic claims) must be understood just along cognitivist semantic lines. Versions of hybrid expressivist-error theory that do not make this assumption can also gain support from the Simple Imperative Argument. I consider them in $\$ 6$.

Error theorists will be quick to point out that they need not give a complete account of everything that might function as a moral claim in order to achieve their polemical purpose of arguing that morality is founded on falsehoods. ${ }^{21}$ This is correct as far as it goes. If you are an error theorist and just have a polemical purpose, then you can limit your analysis of moral discourse to just those contributions to it that appear as non-negative atomic moral claims. It will, indeed, be quite telling if all non-negative atomic moral claims express false beliefs. But some error theorists will want to achieve more than a polemical purpose. A more ambitious error-theoretic aim is to get the semantics, epistemology and metaphysics of morality right, and for this aim a complete account of everything that might function as a moral claim is required. Or more precisely: the ambitious error theorist should (a) show that there is no moral normativity that we have to take into account in our practical deliberation and (b) list the kinds of contributions to moral discourse that commit those who make these contributions to the existence of moral normativity. The ambitious error theorist does not have to account for those contributions to moral discourse that do not commit their utterers to the existence of moral normativity.

I think that error theorists should be ambitious in this sense. This is not the standard interpretation of moral error theory. The standard interpretation goes in terms of non-negative atomic moral claims that express false beliefs. I first clarify

\footnotetext{
${ }^{20}$ In the context of the imperative argument and in defense of this premise, Svoboda, op. cit., p. 44, writes: "an error theorist could hold both that some but not all moral [claims] are used to express false beliefs, and that no moral [claim] is used to expressed a true belief ... yet this would leave many moral [claims] unexplained because it would not offer an explanation of moral [claims] that do not seem to be used to express false beliefs ... an error theorists is not to ignore such moral [claims]."

21 I thank an anonymous reviewer of this journal for this suggestion.
} 
my terminology and then argue that we should prefer my non-standard, ambitious formulation of error theory.

I will call a moral claim that entails that moral normativity exists a substantive moral claim (so a 'claim' as I understand it describes any contribution to moral discourse that has been communicated, not just non-negative atomic claims). Nonsubstantive moral claims do not entail that such moral normativity exists. These kinds of contributions to moral discourse may be relevant to our talk about morals in different ways, for instance because they invite others to make substantive claims. E.g., the question 'is stealing morally wrong?' does not commit its utterer to the existence of moral normativity and is therefore not a substantive moral claim. But it will usually invite the addressee to respond as follows: 'yes (no), stealing is (not) morally wrong' and is therefore relevant to moral discourse.

Why accept this non-standard interpretation of moral error theory? I have three arguments. The first is that only ambitious error theory is consistent with the spirit of error theory. Error theorists care about whether there is moral normativity and they care about which kinds of contributions to moral discourse communicate that this form of normativity exists. Error theorists care about the question whether moral normativity exists because they want to know whether they ought to take this normativity into account in their practical deliberation. I may get into a situation in which I need to decide whether to save a drowning child from a pond or not save her and continue to enjoy my afternoon walk. ${ }^{22}$ In that situation I need to know whether I ought to take the alleged moral reason that I have to save the child into account in my practical deliberation or whether I can limit myself to considering non-moral reasons such as those of prudence and aesthetics. Error theorists do not think that what substantive moral claims describe-moral considerations that we ought to take into account when thinking about what to do-exists. Such normativity, because it has to be objective or irreducible, error theorists think, is "too queer to exist". ${ }^{23}$ And error theorists care about knowing which contributions to moral discourse commit their utterers to communicating that moral normativity exists because they want to know which kinds of contributions to moral discourse they can continue to utter without making this mistake. To this end we ought not to assume from the outset that the only kinds of contributions to moral discourse that can commit the error of communicating the existence of moral normativity are non-negative atomic moral claims like 'stealing is morally wrong.' (Again this 'ought' is a non-moral, epistemic ought).

But is it reasonable to reckon with the possibility that there may be moral claims that do not belong to the set of non-negative atomic moral claims and yet

\footnotetext{
22 See Peter Singer, "Famine, Affluence, and Morality," Philosophy and Public Affairs, vol. 1, no. 3 (1972): 229-243, p. 231.

23 See Olson, op. cit., p. 12n17; also see Wouter F. Kalf “Are Moral Properties Impossible?" Philosophical Studies, vol. 172, no. 7 (2015): 1869-1887. The locus classicus is Mackie, op. cit., p. 38. In this paper I talk loosely about moral normativity, writing that it consists just of reasons (rather than, say, rational requirements) and asserting that these reasons are considerations (rather than, say, facts or relations). These are substantive views in meta-normativity that I cannot argue for in this paper. In the present context I appeal to them merely for ease of exposition; nothing of substance hangs on this for my purposes.
} 
communicate that moral normativity exists? My second reason for preferring the non-standard interpretation of error theory is that this is reasonable. In fact, recent work on imperatives suggests that imperatives can be substantive moral claims in my sense of 'substantive.'

Josh Parsons has argued for cognitivism about imperatives, according to which imperatives are truth-apt and have truth-conditions. ${ }^{24}$ In Parsons' case these truthconditions are facts about what speakers say, and these facts are not moral facts:

If imperatives have truth conditions, what are they? There are varying possible answers to this question, but I think the best is as follows: anything you can say using the imperative mood, you could say instead using a performative. For example, instead of saying 'Attack at dawn!', I could have said 'I command that you to attack at dawn!' The thesis of cognitivism, then, is that imperatives are equivalent to the corresponding performatives, and the performatives in turn are true iff they are so commanded. That is to say: 'Attack at dawn!' means the same as 'I command that you to attack at dawn!' 'I command that you attack at dawn' (spoken by me) is true iff I command that you attack at dawn. ${ }^{25}$

Parsons writes that "imperatives ... are traditionally supposed not to be truth-apt." 26 This is also Svoboda's thought. But suppose that Parsons is right about his cognitivism about imperatives and that imperatives are in fact truth-apt. In that case, though Parsons has not shown that their truth-makers are moral reasons, error theorists need to reckon with the possibility that future analysis reveals that imperatives with moral content express truth-apt beliefs about moral reasons rather than beliefs about what speakers (could) have said. ${ }^{27}$ Error theorists are ill-advised to assume from the get go that only non-negative moral judgments can be substantive.

Other recent work on imperatives has been done by Peter Vranas, who writes:

What exactly is it to "endorse" an imperative sentence? To endorse a declarative sentence is to believe that the sentence is true, but imperative sentences cannot be true. I submit that to endorse an imperative sentence which prescribes that an agent perform an action is to believe that there is a reason for the agent to perform the action. For example, to endorse the imperative sentence "John, do your homework" is to believe that there is a reason for John to do his homework. ${ }^{28}$

\footnotetext{
${ }^{24}$ See Josh Parsons, "Cognitivism about Imperatives," Analysis, vol. 72, no. 1 (2012): 49-54; also see Josh Parsons, "Command and Consequence," Philosophical Studies, vol. 164, no. 1 (2013): 61-92.

25 See Parsons, "Cognitivism”, p. 49.

26 See Parsons, "Cognitivism”, p. 49.

27 See Parsons, "Cognitivism”, p. 49.

28 See Peter Vranas, "In Defense of Imperative Inference," Journal of Philosophical Logic, vol. 39, no. 1 (2010): 59-71; also see Peter Vranas, "New Foundations for Imperative Logic: Pure Imperative Inference," Mind, vol. 120, no. 478 (2015): 369-446; Hannah Clark-Younger, "Imperatives and the More Generalised Tarski Thesis," Thought vol. 3, no. 4 (2014): 314-320.
} 
From Vranas we learn that imperatives can have close ties to reasons; including, perhaps, moral reasons. Take the imperative sentence 'John, save the drowning child form the pond.' On Vranas' account, to endorse this sentence is to believe that there is a moral reason for John to save the drowning child from the pond. However, as Vranas also says that imperative sentences cannot be true, he does not accept cognitivism about imperatives. The thought here is that if imperatives stand in this intimate relation to beliefs about the existence of moral reasons then perhaps future analysis will reveal that imperatives with moral content express truth-apt beliefs about moral reasons. Again error theorists should be worried about imperatives and not accept too quickly that they just need to look at non-negative atomic moral claims. Indeed, combining Parsons and Vranas gets us a view about imperatives on which they express truth-apt beliefs whose truth-makers are moral reasons in the very same way as that in which non-negative atomic moral claims express truth-apt beliefs whose truth-makers are moral reasons.

The third and final reason to take non-standard, ambitious error theory seriously and not to be content with polemical error theory has to do with contingency planning. Suppose you want to be an error theorist and suppose that you agree that it is in the spirit of error theory to list all the kinds of moral claims that communicate the existence of moral normativity. In that case it would be advisable if you had an objection to Svoboda's argument-just in case.

Svoboda puts forward the Simple Imperative Argument to convince error theorists to become hybrid expressivist-error theorists. I think that this argument fails because it fails to convince error theorists that there are contributions to moral discourse that are (a) substantive and (b) not couched as non-negative atomic moral claims. In the next section I reformulate the Simple Imperative Argument and turn it into an argument that does not fail for this reason. In the sections that follow I return to the question whether imperatives express truth-apt beliefs about moral normativity, and whether this matters for the tenability of pure error theory.

\section{The Improved Imperative Argument}

The Simple Imperative Argument states that moral claims that do not express beliefs are counter-examples to error theory. This is a good argument iff imperatives are substantive claims and express desires (or if imperatives express desires and beliefs, in which case not version (1) but for instance version (4) of hybrid expressivist-error theory must be accepted, a possibility I discuss in §6). So a much more interesting argument goes like this:

\section{Improved Imperative Argument}

P5 We must distinguish between substantive and non-substantive moral claims

P6 Error theorists are obliged to account for substantive moral claims only, and they have to argue that they express (false) beliefs

P7 Imperatives are substantive moral claims 
C2 Therefore, error theory stands or falls with the correct analysis of imperatives [From P5-P7]

P8 If imperatives express desires, hybrid expressivist-error theory is true

P9 Imperatives express desires

C3 Therefore, hybrid expressivist-error theory is true [From P8-P9] ${ }^{29}$

The question we must now answer is: are imperatives substantive moral claims? I try to do this in the next section. But first I respond to an objection.

You might worry that if error theorists ought to condemn all substantive moral claims to the realm of systematic falsity, then error theory will be incoherent. ${ }^{30}$ Suppose ' $\mathrm{X}$ is right' and ' $\mathrm{X}$ is not right' are both substantive moral claims. In that case you cannot deny the one without denying the other and the theory you end up with, because it entails that they are both false, is inconsistent.

There are at least two possible responses. First, though I have decided to talk, in this paper at least, about moral claims as being all systematically false (following Svoboda), error theorists are actually not required to say that the moral claims they find problematic are all systematically false. An error theorist who prefers to develop her theory along the lines of presupposition failure will say that moral claims presuppose, vitally though erroneously, the existence of moral normativity. ${ }^{31}$ For example, take 'the present king of France is bald' and its negation 'the present king of France is not bald.' They both presuppose, vitally though erroneously, the existence of the present king of France. The presupposition error theorist can say that ' $\mathrm{X}$ is right' and ' $\mathrm{X}$ is not right' are both neither true nor false. This saves her from being inconsistent. But following Svoboda, who wants systematically false beliefs for the error theorist, the presupposition error theorist can also say that ' $\mathrm{X}$ is right,' because it is a non-negative atomic claim, entails its false presuppositions and is therefore false. ${ }^{32}$ Adding to this, the presupposition error theorist can say that other sorts of claims, like ' $\mathrm{X}$ is not right,' because they are not couched as nonnegative atomic claims, do not entail their presuppositions, and are therefore neither true nor false. This also saves error theory from inconsistency and allows her to continue to say that non-negative atomic moral claims are false because other kinds

\footnotetext{
29 There are actually two separate arguments; first there is P5-C2, which paves the way for P8-C3; however, I will refer to these two arguments as the Improved Imperative Argument (in the singular) for ease of reference.

30 See Pigden, op. cit., pp. 450-454; also see Olson, op. cit., pp. 11-15. I thank an anonymous referee for this journal for pressing me on this point.

31 See Richard Joyce, Myth, pp. 6-9; also see Olson, ibid., pp. 9-11; Stephen Finlay, "The Error in the Error Theory," Australasian Journal of Philosophy, vol. 86, no. 3 (2008): 347-369, p. 347; Russ ShaferLandau, "Error Theory and the Possibility of Normative Ethics," Philosophical Issues, vol. 15, no. 1 (2006): 107-120 p. 108; Russ Shafer-Landau and Terence Cuneo, "Moral Error Theories," in ShaferLandau, R. and T. Cuneo (eds.) Foundations of Ethics: an Anthology (London: Blackwell, 2007): 9-12, p. 9. No one in this list accepts presupposition moral error theory; however, this does not show that the view isn't possible and it also doesn't show that the view isn't attractive.

32 See Mandy Simons, "Foundational Issues in Presupposition," Philosophy Compass vol. 1, no. 4 (2006): 357-72, pp. 365-366.
} 
of moral claims, such as negated atomic claims, can be substantive and not true because they are neither true nor false.

The second possible response is to deny that ' $\mathrm{X}$ is right' and ' $\mathrm{X}$ is not right' are both substantive moral claims. Perhaps substantive claims are just: ' $\mathrm{X}$ is right' and the imperative 'do X!' We are not inconsistent if we say that these two kinds of contributions to moral discourse are both false. How should error theorists analyse ' $\mathrm{X}$ is not right' in this case? One answer, which I shall assume works in this paper, is due to Jonas Olson, who denies that negative (or as he calls them, 'negated') atomic moral claims entail anything about the existence of moral normativity. ${ }^{33}$ You might think that a moral claim like ' $\mathrm{X}$ is not right,' though it does not entail anything about the existence of moral normativity, conversationally implicates that ' $\mathrm{X}$ is permissible.' But, says Olson, conversational implicatures are cancellable-they can be denied consistently with continuing to accept the utterance that carries the implication. ${ }^{34}$ Take Abe and Bert who are discussing whether Pete will be at the meeting on time. Abe says 'Pete's car broke down.' Given the context of this conversation, Bert justifiably infers that Pete will not be on time. 'Pete's car broke down' conversationally implicates that Pete will not make it on time in this context. But Abe, realising that Pete can attain this conclusion via this justification, can cancel the implicature by adding: 'but mind you, Pete will be there-he'll go by bike.' This is a particularised conversational implicature because it depends on features of the context of the utterance to arise-generalized conversational implicatures do not depend on context. ${ }^{35}$ So, ' $\mathrm{X}$ is not right' may feel like it is substantive, and so you might be lured into thinking that it is a substantive claim, and therefore you might start to worry about consistency. But actually ' $\mathrm{X}$ is not right' is not substantive, and your sense that it is substantive can be explained away by pointing to the cancellable conversational implicature that it carries.

\section{Against the Improved Imperative Argument}

We are looking for a moral claim that doesn't take the form of a non-negative atomic moral claim, is substantive, and expresses a desire. In the previous section I argued that Svoboda has to convince us that imperatives are like this for his imperative argument against pure error theory and in favour of hybrid expressivisterror theory to work. There are two other possible scenarios though, so let us call this option (A). Option (B) obtains if we have a moral claim that does not take the form of a non-negative atomic moral claim, is substantive, and expresses a belief. Option (C) obtains if we have a moral claim that does not appear as a non-negative atomic moral claim but isn't substantive either.

Let's start with option (B). In $\S 3$ I discussed Parsons' cognitivism about imperatives according to which imperatives have truth-conditions that are not moral

\footnotetext{
33 See Olson, op. cit., pp. 14-15.

34 Paul Grice, Studies in the Ways of Words (Cambridge, MA: Harvard University Press 1989), p. 26.

35 See Caj Strandberg, "A Dual Aspect Account of Moral Language," Philosophy and Phenomenological Research, vol. 84, no. 1 (2012): 87-122, p. 93.
} 
reasons. I also discussed Vranas' theory on which imperatives, though they don't have truth-conditions, nevertheless have a close tie to the existence of moral reasons. I argued that we might combine their accounts and get what we might call Parsons/Vranas cognitivism about moral imperatives. On this account, imperatives express beliefs that have truth-conditions that are moral reasons. If this is what we get though, then error theory wins. After all, the error theorist says (and this is not under dispute in this paper) that the truth-makers that these beliefs require do not exist, which entails that imperatives are systematically false. This is exactly the same situation that non-negative atomic moral claims are in, which express beliefs that require moral reasons as their truth-makers, but these reasons do not exist and render all the non-negative atomic moral claims false.

Now let's consider option (C). Do imperative express desires? Mark Schroeder thinks that which mental state(s) imperatives express depends on which theory of the expression relation we accept. ${ }^{36}$ When we think of the expression relation as a causal relation then the mental state that causes the utterance of a moral claim is what this claim expresses. Suppose you participate in an anti-war protest and shout 'Stop war!' Svoboda claims that there will be "contextual evidence [that] suggests that the utterance is used to express a disapproving attitude toward war rather than a belief." 37 You will be in some sort of emotional state and feel disapproval towards war-enter the causal theory of the expression relation, and this conative state of mind is what your imperative expresses. Ayer's early and influential expressivist account of moral language invites the causal interpretation of the expression relation. He writes that moral claims are "ejaculations" of emotions. ${ }^{38}$ So when we assume the causal interpretation of the expression relation, it seems that imperatives express desires.

Suppose that imperatives do express desires. Then there are two options: imperatives are substantive or they aren't. If they aren't substantive then even the ambitious error theorist does not have to worry about them, for then they don't communicate that moral normativity exists. Again, error theory wins. Can we have a moral claim-for example an imperative- that is not a non-negative moral claim, and, though substantive, does not express a belief? This would be option (A).

We currently have no method for determining which sorts of moral claims are substantive and which ones are not. To overcome this difficulty I propose to focus not on thinking about the conditions under which moral claims are substantive but on seeing whether we can formulate a criterion for excluding claims from belonging to the class of substantive moral claims. In this spirit I propose the

\section{Desire Exclusion Criterion}

Moral claims are not substantive if they just express desires

We should accept the Desire Exclusion Criterion because it deploys a very standard way of thinking about desires and beliefs, which concerns their direction of fit:

\footnotetext{
36 See Mark Schroeder, "Expression for Expressivists," Philosophy and Phenomenological Research, vol. 76, no. 1 (2008): 86-116.

37 Svoboda, op. cit., p. 44.

38 See Ayer, op. cit., p. 130.
} 
The distinction [between beliefs and desires] is in terms of the direction of fit of mental states to the world. Beliefs aim at being true, and their being true is their fitting the world; falsity is a decisive failing in belief, and false beliefs should be discarded; beliefs should be changed to fit the world, not vice versa. Desires aim at realization, and their realization is the world fitting with them; the fact that the indicative content of a desire is not realised in the world is not yet a failing in the desire, and not yet any reason to discard the desires; the world, crudely, should be changed to fit with our desires, not vice versa. ${ }^{39}$

Claims that express desires don't have to be discarded if we find that the world does not correspond to them because they don't represent the world as it is. They only represent the world as we want it to be. So it would be wrongheaded to continue to say that moral claims that express just desires are substantive moral claims, for substantive claims represent moral reality as it is, and claims that just express desires do not represent reality it is. So imperatives, if they express desires, cannot be substantive moral claims. Option (A) is not possible and always collapses into option (C); but option (C) does not hurt error theory.

I can now formulate my first conclusion. Once we accept the Improved Imperative Argument with the Desire Exclusion Criterion and therefore let the issue of which mental state(s) imperatives express depend on which theory of the expression relation we accept, then version (1) of hybrid expressivist-error theory is out of reach. For then either imperatives express desires, are therefore not substantive, and therefore do not matter for even ambitious error theory. Or else they express beliefs and will therefore be systematically false. Either way, error theory wins. Given the Desire Exclusion Criterion, we cannot have a scenario in which imperatives express desires and are substantive.

\section{Does It Matter if Imperatives Express both Beliefs and Desires?}

But does it matter if imperatives express both beliefs and desires, as some hybrid expressivist-error theorists might claim? Take the following views:

Ecumenical expressivism: A sentence of the type " $\varphi$ ing is wrong" expresses a moral [claim] which consists of (1) a non-cognitive state, and (2) a belief. However, (3) the moral sentence is not true by virtue of the belief in (2) being true. Ecumenical cognitivism agrees with (1) and (2), but states that (3) the moral sentence is true if the belief referred to in (2) is true. ${ }^{40}$

One might think that it is obvious that the issue of whether moral claims express both beliefs and desires matters for the present debate between pure error theorists and hybrid expressivist-error theorists. For now we can abandon version (1) of hybrid expressivist-error theory

\footnotetext{
39 See Mark Platts, Ways of Meaning (London: Routledge \& Kegan Paul, 1979), p. 257.

40 See Strandberg, op. cit., p. 90 (italics are in original).
} 
(1) Some moral claims must be understood just along non-cognitivist semantic lines and every other moral claim must be understood just along cognitivist semantic lines

and instead we accept, e.g., version (4)

(4) Some moral claims must be understood along cognitivist lines and every other moral claim must be understood as combining cognitivist and noncognitivist semantics

However, we cannot conclude immediately from the claim that moral claims express both beliefs and desires that hybrid expressivist-error theory must be preferred to pure error theory. As I suggested in $\$ 3$, not just any theory of moral discourse that combines elements of cognitivism and non-cognitivism deserves to be called a hybrid theory. Recall hybrid theory version (1). If it turns out that all substantive claims just express beliefs then it no longer matters if non-substantive claims express desires, whims, emotions or what-have-you. We do not have a counter-example to error theory nor, given the Desire Exclusion Criterion, do we have a genuinely hybrid theory if any or all non-substantive claims express noncognitive attitudes. To insist otherwise is to insist on a distinction without a difference. We would have a distinction with a difference if it turns out that error theory must agree that there are substantive moral claims that require noncognitivist semantics. But this scenario cannot obtain.

We can apply a similar argument to the possibility that (4) is true. If imperatives express both desires and beliefs then we must settle on a theory of moral discourse that cannot be fully cognitivist. But again it is not clear that we immediately have a counter-example to pure error theory. This is because there is the possibility that desires are doing all the philosophical work and that the beliefs that are being expressed are merely epiphenomena. Ecumenical expressivism as defined above is not clear on this. It could mean that beliefs contribute to the meaning of the moral claim, but it could also mean that the belief, though expressed by the moral claim, does not contribute to its meaning. If beliefs are not involved in this task and desires are doing all the work then, by the Full Desire Exclusion Criterion, the relevant claim is not substantive because it expresses a desire that does all the work and expresses a belief as a mere epiphenomenon:

\section{Full Desire Exclusion Criterion}

Moral claims are not substantive if they express desires that are doing all the philosophical work of giving these claims their meaning and any beliefs they may express as well are mere epiphenomena

If this is true then pure error theory wins again. Some moral claims express substantive but false beliefs (non-negative atomic claims). Some other claims express desires and are therefore not substantive moral claims (imperatives). They also express beliefs, but these beliefs are not doing any philosophical work (do not contribute to the claim's meaning) are just epiphenomena, and so to nonetheless insist that we must speak of a hybrid expressivist-error theory is to insist on a distinction without a difference. We would have a distinction with a difference if the 
belief that also gets expressed is doing philosophical work incompatible with error theory, requiring error theory to accept that we have substantive moral claims because they express beliefs but that part of their meaning is supplied by desires. But this has not been shown. As formulated, the Improved Imperative Argument accepting the idea that moral claims can express both beliefs and desires overstates its case, assuming without argument that both the desires and beliefs that imperatives express contaminate their meanings.

The same consideration works in the other direction as well. If beliefs are doing all the philosophical work in claims that express both beliefs and desires then these claims are simply substantive, cognitivist, and false. The fact that any desires that also get expressed are mere epiphenomena does not give us sufficient reason to consider calling our error theory 'hybrid expressivist-error theory.' To insist on doing this is to insist on accepting a distinction without a difference. Things would be different if we knew that our best theory of the expression relation determines that imperatives express both beliefs and desires such that both are doing important semantic work and therefore that a fully cognitivist metaethical theory like error theory is not credible. But this is yet to be shown.

I conclude that imperatives do not (yet) give error theorists a reason to accept hybrid expressivist-error theory. The Simple Imperative Argument is not plausible because it fails to recognise the distinction between substantive and non-substantive moral claims. And the Improved Imperative Argument, though it solves this problem, is either implausible (if we assume that moral claims express either beliefs or just desires) or, as I argued in this section, overstated (if we assume that moral claims express both beliefs and desires).

How about the remaining versions (2), (3) and (5) of hybrid expressivist-error theory?

(2) Every moral claim must be understood as combining elements of noncognitivist and cognitivist semantics and never just along non-cognitivist semantic lines and never just along cognitivist semantic lines

(3) Some moral claims must be understood just along non-cognitivist semantic lines, some other moral claims must be understood just along cognitivist semantic lines and the remaining moral claims must be understood as combining elements of non-cognitivist and cognitivist semantics

(5) Some moral claims must be understood along non-cognitivist lines and every other moral claim must be understood as combining cognitivist and noncognitivist semantics

Version (2) fails because it is overstated, just like version (4). Versions (3) and (5) are overstated when they take moral claims to express both beliefs and desires. The additional fact that these versions state that some kinds moral claims require a different "pure" semantics (i.e., either fully cognitivist or fully non-cognitivist) than the "pure" semantics (fully cognitivist or fully non-cognitivist) that other claims require does not help either. For then we must go back to options (A)-(C) discussed in the previous section, and conclude that we either get more false beliefs, which is a result amenable to error theory (B), or else claims that are not substantive (C). There can be no moral claim that expresses a desire and is substantive $(\neg \mathrm{A})$. This assumes, 
of course, that non-negative atomic moral claims express (false) beliefs. If the pure expressivist is right that these kinds of moral claims do not express beliefs but nontruth apt non-cognitive states instead then error theory is false. But if the pure expressivist is right then Svoboda cannot have his hybrid-expressivist error theory either.

\section{Moral Motivation and Radical Error}

Svoboda lists two other arguments in favour of hybrid expressivist-error theory and against pure error theory. The first argument is that pure error theory cannot, whereas a hybrid expressivist-error theory can, account for the phenomenon of moral motivation. Svoboda assumes a standard Humean moral psychology according to which belief-like mental states and desire-like mental states are the only kinds of mental states that exist and according to which belief-like states have no motivational power and desire-like states do have motivational power. But this Humean moral psychology has been contested. Jonathan Dancy has argued that "a desire is never a necessary part of what motivates." ${ }^{41} \mathrm{I}$ do not have the space to defend Dancy here; I just note that Svoboda's argument is too quick. For all Svoboda says, Dancy might be right.

Svoboda's second argument for hybrid expressivist-error theory and against pure error theory starts with the claim that error theory entails that all are moral claims are false and continues to assert that this renders error theory implausible. Svoboda then claims that hybrid expressivist-error theory can say that at least some moral claims are not false because some moral claims, as they express non-truth-apt noncognitive states, are neither true nor false. Svoboda concludes that this is less implausible than pure error theory because we no longer have a radical error, understood as the systematic falsity of moral claims, in moral discourse.

One response is that this isn't much of an improvement. I think that what we (including Svoboda) find worrisome about radical error is that it forbids us to say that at least some moral claims (e.g., 'wanton killing is morally wrong') are true. But if this is what we are worried about then we will not be worried much less if we learn that, though all moral claims are untrue, it is not the case that all moral claims are false because some claims are neither true nor false. 'Wanton killing is morally wrong' is not true either way.

A second response is to mitigate the implausibility of the claim that all moral claims are false. First, we can invoke science; in particular, the theory of evolution by natural selection. ${ }^{42}$ We have evolved to categorise aspects of the world using moral concepts because this proved to be an effective way to ensure that our genes make it into the next generation-and this works regardless of whether or not we correctly categorise the world using moral concepts. So, as we are hardwired to see the world through a moral lens we will probably continue to act morally even if we believe, after error theory, that all (substantive) moral claims are false. Second,

\footnotetext{
${ }^{41}$ See Jonathan Dancy, Practical Reality (Oxford: Oxford University Press, 2001), p. 13.

42 See Joyce, Myth, p. 135.
} 
though I might be an error theorist and believe that all substantive moral claims are untrue, I will still have many prudential reasons to continue to categorise the world using moral concepts. ${ }^{43}$ For example, I don't want you to think that I am a bad person. This prudential justification for continuing to use moral concepts after error theory also makes it more likely that I do the morally right thing and refrain from doing what is morally wrong. Error theory's claim that there is a radical error in moral discourse does not make it as implausible as Svoboda portrays it to be.

\section{Conclusion}

According to Toby Svoboda there are three arguments for hybrid expressivist-error theory and against pure error theory. These are the moral motivation, the radical error and the imperative arguments. I have argued that these arguments do not currently compel error theorists to become hybrid expressivist-error theorists. ${ }^{44}$

Open Access This article is distributed under the terms of the Creative Commons Attribution 4.0 International License (http://creativecommons.org/licenses/by/4.0/), which permits unrestricted use, distribution, and reproduction in any medium, provided you give appropriate credit to the original author(s) and the source, provide a link to the Creative Commons license, and indicate if changes were made.

\footnotetext{
${ }^{43}$ See Olson, op. cit., pp. 178-198.

${ }^{44}$ I presented an earlier version of this paper at the Philosophy Colloquium, Faculty of Philosophy, University of Groningen and the Seminar for Analytic Philosophy, University of Utrecht. I thank Herman Philipse, Michael Klenk, Julia Hermann, Jeroen Hopster, Joeri Witteveen, Bart Streumer, Daan Evers, and Pauline Kleingeld for their feedback.
} 